\title{
Report on the topic: "Problems of using datum-based methods to form deviations and surface waviness"
}

\author{
Raport na temat” „Problemy zastosowania metod odniesieniowych \\ do pomiarów zarysów kształtów i falistości powierzchni"
}

\author{
STANISŁAW ADAMCZAK \\ KRZYSZTOF STEPIEŃ \\ PAWE ZMARZ Y Y \\ THOMAS G. MATHIA*
}

DOI: https://doi.org/10.17814/mechanik.2020.3.8

The paper discusses the state-of-the-art on research and development of activities relating to wider application of datum-based methods in the field of measurements of surface texture of machine parts. Despite the fact that datumbased methods are well-known, in hitherto practice their application area has been limited. Research activities carried out by authors indicate that datum-based methods can be very useful as a part of computer-aided measurement systems allowing conducting measurements directly on a machine tool (in-situ measurements). One of the results of the research work conducted by authors was proving that datum-based methods can be applied to evaluate cylindricity deviations and, with some limitations, to evaluate surface waviness of machine parts.

KEYWORDS: measurement, form deviation, waviness, datum-based methods

Przedstawiono obecny stan badań i prac rozwojowych dotyczących szerszego wykorzystania metod odniesieniowych do pomiarów struktury geometrycznej powierzchni. Chociaż metody te są znane, to dotychczas były stosowane w ograniczonym zakresie. Przeprowadzone prace wykazały dużą przydatność tych metod w skomputeryzowanych systemach kontroli elementów w trakcie realizacji procesu bezpośrednio na stanowiskach wytwórczych, a nawet bezpośrednio na obrabiarce. Efektem badań przeprowadzonych przez autorów było m.in. wykazanie, że metody odniesieniowe mogą być stosowane do oceny zarysu walcowości i w pewnym ograniczonym zakresie - do kontroli falistości powierzchni.

SŁOWA KLUCZOWE: pomiar, odchyłka kształtu, falistość, metody odniesieniowe

\section{Wprowadzenie}

Dynamiczny rozwój nowoczesnego przemysłu stawia wysokie wymagania w stosunku do wytwarzanych części maszyn. Produkowane elementy mechaniczne powinny się cechować wysoką jakością i niezawodno- ścią. Dodatkowo w przemyśle dąży się do zwiększenia wydajności oraz redukcji kosztów produkcji z zachowaniem jej wysokiej jakości.

Struktura geometryczna powierzchni to zbiór wszystkich nierówności powierzchni obejmujących odchyłki kształtu, falistość oraz chropowatość. Wartości tych parametrów są uzależnione od wielu czynników, m.in. od: technologii wykonania, parametrów obróbkowych, stanu technicznego obrabiarki, właściwości materiału obrabianego oraz od czynnika ludzkiego [1].

Jednymi z najważniejszych błędów kształtu są odchyłki okrągłości, falistości oraz walcowości powierzchni cylindrycznych, ponieważ detale okrągłe stanowią liczną grupę wśród elementów mechanicznych. Jest to istotne zwłaszcza w przypadku łożysk tocznych [2, 3]. Kilkadziesiąt lat temu nie przykładano dużej wagi do pomiaru tych odchyłek, ponieważ uważano, że nie mają one większego znaczenia w projektowanych urządzeniach oraz mechanizmach. Teraz już wiadomo, że błędy kształtu, a przede wszystkim odchyłki okrągłości oraz falistości powierzchni cylindrycznych, mogą powodować powstawanie drgań i szumów części maszyn, które wykonują w trakcie eksploatacji ruch obrotowy lub posuwisto-zwrotny $[3,4]$. Dlatego pomiar tych odchyłek jest tak istotny w przemyśle.

Należy dodać, że zastosowanie najpowszechniejszej metody bezodniesieniowej do pomiaru dużych elementów walcowych jest znacznie utrudnione ze względu na ograniczoną przestrzeń roboczą stolika pomiarowego, czasochłonność oraz trudność związaną z przeprowadzeniem pomiaru [6]. Metoda ta ma głównie zastosowanie laboratoryjne i rzadko jest przydatna do oceny odchyłki okrągłości lub falistości dużych walców, występujących m.in. w przemyśle hutniczym, okrętowym czy włókienniczym, gdyż pomiar musi być wykonywany bezpośrednio na obrabiarce lub stanowisku roboczym. Do tego typu pomiarów można wykorzystywać metody odniesieniowe [3, 6].

\footnotetext{
* Prof. dr hab. inż. Stanisław Adamczak dr h.c. multi, adamczak@tu.kielce.pl, https://orcid.org/0000-0002-7797-6330 - Politechnika Świętokrzyska, Kielce, Polska

Dr hab. inż. Krzysztof Stępień, prof. PŚk, kstepien@tu.kielce.pl, https://orcid.org/0000-0001-7066-0299 - Wydział Mechatroniki i Budowy Maszyn Politechniki Świętokrzyskiej, Kielce, Polska

Dr inż. Paweł Zmarzły, pzmarzly@tu.kielce.pl, https://orcid.org/0000-0003-3717-1500 - Wydział Mechatroniki i Budowy Maszyn Politechniki Świętokrzyskiej, Kielce, Polska

Dr hab. inż. Thomas G. Mathia, thomas.mathia@ec-lyon.fr, https://orcid.org/0000-0001-9319-7380 - Centre National de la Recherche Scientifique (CNRS), Laboratoire de Tribologie et Dynamique des Systèmes (LTDS), École Centrale de Lyon, Francja
} 


\section{Metody pomiaru zarysów okrągłości, falistości oraz walcowości elementów cylindrycznych}

Intensywny rozwój nowych technologii narzuca opracowanie systemów pomiarowych, które powinny nie tylko wykazywać dużą dokładność, lecz także być łatwe w obsłudze, uniwersalne oraz dostosowane do potrzeb produkcyjnych.

W warunkach przemysłowych oraz laboratoryjnych można wyróżnić dwie główne grupy metod pomiaru zarysów okrągłości, falistości i walcowości powierzchni cylindrycznych. Są to metody bezodniesieniowe oraz odniesieniowe. Dodatkowo odchyłki te można badać za pomocą przyrządów pomiarowych opartych na współrzędnościowej technice pomiarowej.

Każda z wymienionych metod ma pewne wady i zalety. Metody bezodniesieniowe pozwalają uzyskać bardzo wysoką dokładność, lecz ich zastosowanie do pomiaru dużych elementów cylindrycznych w warunkach przemysłowych jest znacznie utrudnione. Natomiast metody odniesieniowe można stosować do pomiaru odchyłki okrągłości dużych elementów walcowych, jednakże ich dokładność jest mniejsza niż metod bezodniesiowych. Na rys. 1 przedstawiono podział metod pomiaru odchyłki okrągłości.

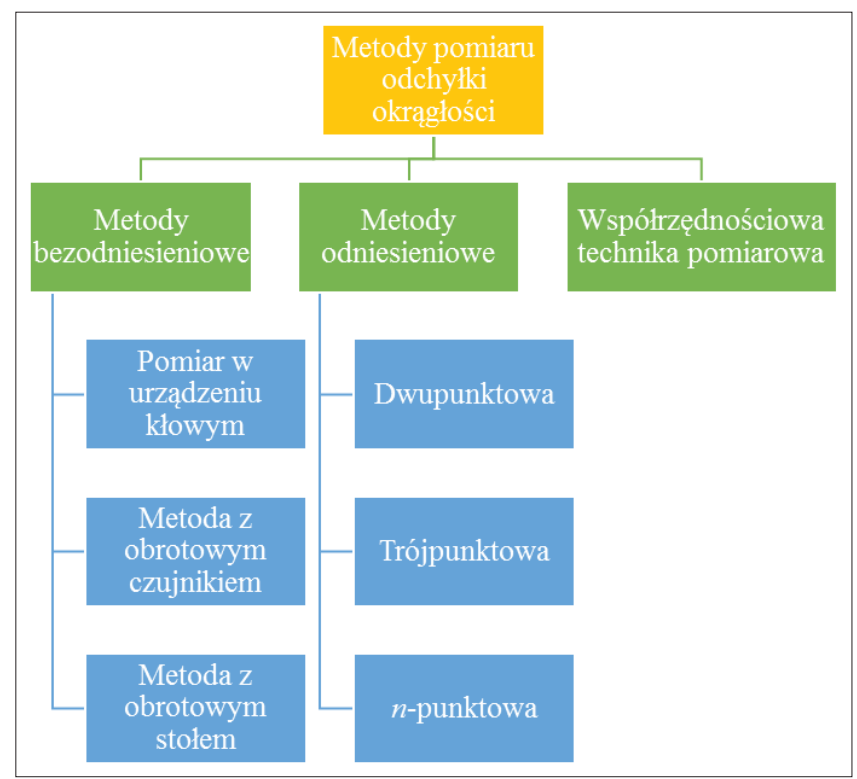

Fig. 1. Classification of methods for measuring roundness, waviness and cylindricity

Rys. 1. Schemat blokowy przedstawiający podział metod pomiaru zarysów okrągłości, falistości oraz walcowości

\section{Metody bezodniesieniowe}

Metody bezodniesieniowe - zwane również metodami pomiaru zmian promienia - są najbardziej rozpowszechnione w przypadku oceny odchyłki kształtu elementów cylindrycznych.

Jednym z pierwszych, a zarazem najprostszych sposobów oceny odchyłki okrągłości metodą bezodniesieniową jest pomiar w urządzeniu kłowym. Mierzony element walcowy zamocowany jest w kłach i wykonuje ruch obrotowy, natomiast czujnik pomiarowy jest ustawiony prostopadle do osi mierzonego elementu (patrz rys. 2).

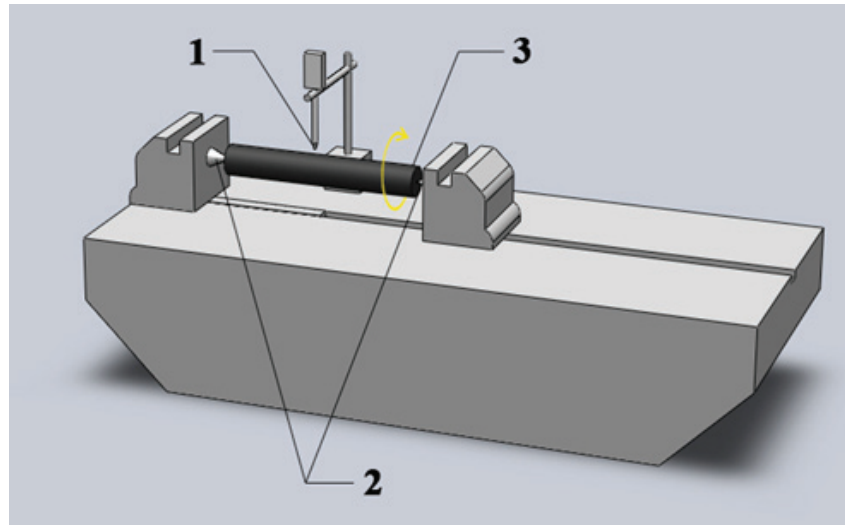

Fig. 2. Diagram of the claw device: 1 - measuring sensor, 2 - claws, 3 - measured object

Rys. 2. Schemat przyrządu kłowego: 1 - czujnik pomiarowy, 2 - kły, 3 - mierzony przedmiot

Pomiar w urządzeniu kłowym jest chętnie stosowany w warunkach przemysłowych, ponieważ jest szybki i prosty, a urządzenie pomiarowe - tanie. Dzięki zastosowaniu czujników cyfrowych oraz oprogramowania komputerowego można wyeliminować błędy systematyczne, dokonać oceny sumarycznych błędów przypadkowych oraz przedstawić wyniki pomiarowe w przejrzystym raporcie. Ograniczeniem tej metody jest fakt, że mierzony przedmiot musi mieć dokładnie wykonane nakiełki.

Kolejnym sposobem realizacji metody pomiaru zmian promienia jest wykorzystanie przyrządów stacjonarnych podzielonych na dwie grupy. Pierwsza z nich dotyczy przyrządów z obrotowym czujnikiem (rys. 3a), gdzie czujnik obraca się wokół elementu usytuowanego na nieruchomym stoliku. Natomiast druga grupa metod dotyczy przyrządów pomiarowych z obrotowym stołem (rys. $3 b$ ). W tym przypadku stolik z mierzonym przedmiotem obraca się wokół nieruchomego czujnika pomiarowego.

Istotną zaletą metod $\mathrm{z}$ obrotowym czujnikiem lub stołem jest wysoka dokładność pomiarowa, rzędu kilkunastu nanometrów. Natomiast jednym z podstawowych ich ograniczeń jest mała przestrzeń robocza stolika pomiarowego (patrz rys. 3). Nie można tymi metodami badać elementów walcowych o dużych

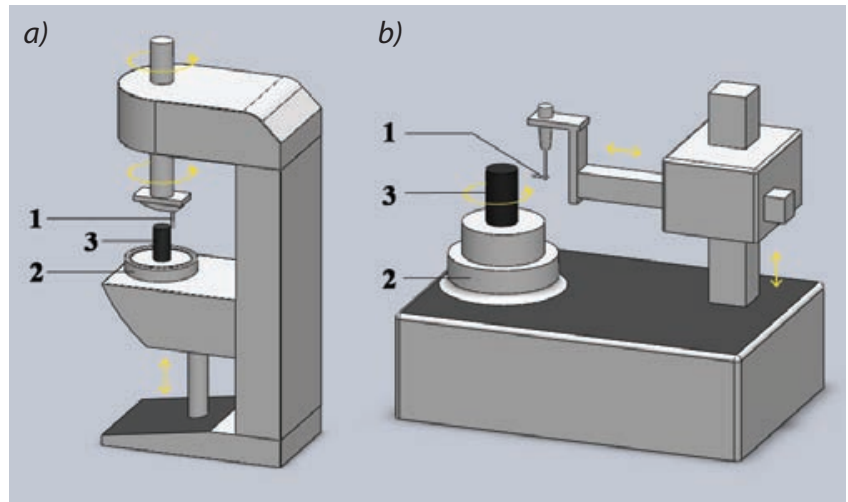

Fig. 3. Principle of the operation of the device for measuring roundness by a radial method: $a$ ) an instrument with a rotary sensor, $b$ ) an instrument with a rotary table; 1 - measuring sensor, 2 - measuring table, 3 - measured object

Rys. 3. Zasada działania przyrządu do pomiaru zarysów okrągłości metodą bezodniesieniową: $a$ ) obrotowy czujnik, $b$ ) obrotowy stolik; 1 - czujnik pomiarowy, 2 - stolik pomiarowy, 3 - mierzony przedmiot 
wymiarach i masie. Ma to duże znaczenie w przemyśle ciężkim, tj. energetycznym i hutniczym, a także włókienniczym i papierniczym, gdzie występują duże elementy walcowe i pomiar ich odchyłek okrągłości oraz falistości należy niejednokrotnie przeprowadzać bezpośrednio na obrabiarce lub roboczym stanowisku kontrolnym. Kolejną wadą tych metod jest czasochłonność oraz trudność związana z centrowaniem mierzonego przedmiotu, co znacznie zmniejsza wydajność pomiarową i kwalifikuje te metody głównie do zastosowań laboratoryjnych. Ze względu na to, że przyrządy pomiarowe oparte na metodzie pomiaru zmian promienia są wyspecjalizowane, ich cena jest wysoka, a zastosowanie - zawężone (pomiar odchyłki okrągłości, prostoliniowości, walcowości itp.).

\section{Metody odniesieniowe}

Metody odniesieniowe, oparte na metodzie pryzmowej (ang. $V$-block), początkowo były mało dokładne i stosowano je jedynie do szacunkowej oceny odchyłki okrągłości. Do ich realizacji wykorzystywano głównie płytę pomiarową i czujnik pomiarowy (metoda dwupunktowa) lub pryzmę pomiarową i czujnik pomiarowy (metoda trójpunktowa). Punkty styku przedmiotu mierzonego z płytą lub pryzmą pomiarową to punkty podparcia $\left(S_{2}\right.$ i $\left.S_{3}\right)$, natomiast punkt styku końcówki czujnika z powierzchnią mierzoną to punkt pomiarowy $\left(S_{1}\right)$. Położenie tych punktów względem obranego wcześniej układu współrzędnych określają parametry metody odniesieniowej, czyli kąty $\alpha$ oraz $\beta$. Kąt $\alpha$ jest kątem pomiędzy styczną do podpory mierzonego przedmiotu a osią $Y$ (patrz rys. 4). Kąt $2 \alpha$ również określa rozwarcie pryzmy pomiarowej. Natomiast kąt $\beta$ występuje pomiędzy kierunkiem przemieszczania się końcówki pomiarowej czujnika a osią $X$.

Charakterystyczne dla metody odniesieniowej jest to, że różnica między maksymalnym i minimalnym

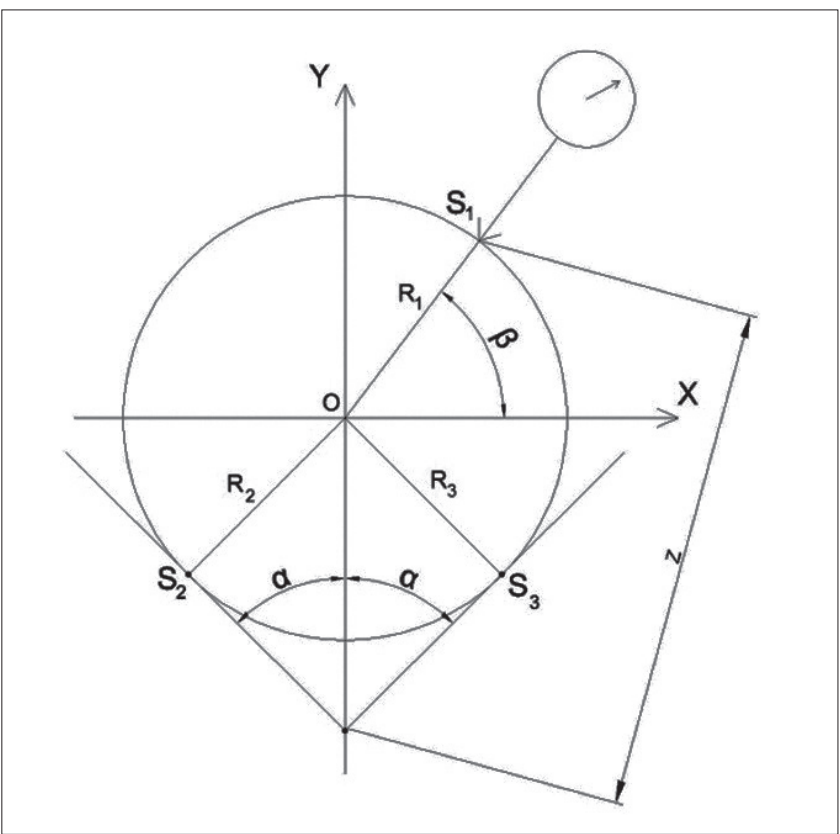

Fig. 4. Principle of measuring of roundness deviation by the datum-based method [8]

Rys. 4. Zasada pomiaru odchyłki okrągłości metodą odniesieniową [8]

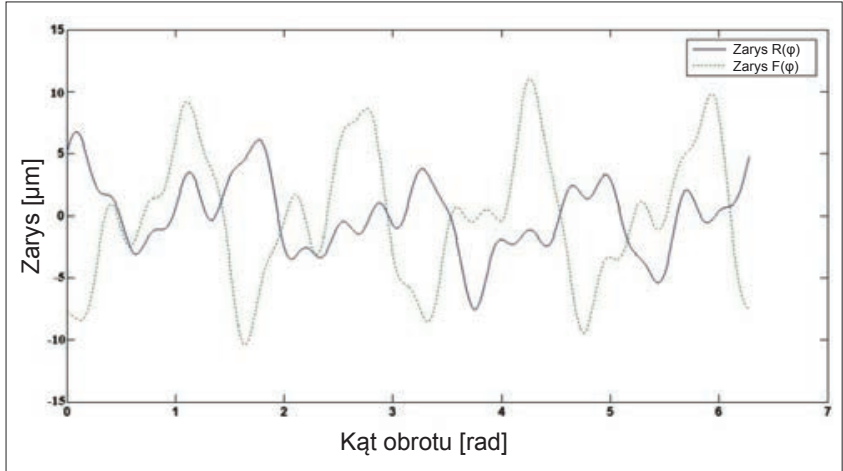

Fig. 5. Exemplary comparison of the sensor readings $F(\varphi)$ and an actual profile $R(\varphi)$

Rys. 5. Przykładowe porównanie zarysu $F(\varphi)$ zmierzonego czujnikiem pomiarowym i zarysu rzeczywistego $R(\varphi)$

wskazaniem czujnika pomiarowego $\Delta F$ nie jest równa rzeczywistej odchyłce okrągłości $\Delta Z$ (patrz rys. 4), ponieważ wartość sygnału uzyskanego z czujnika pomiarowego zależy od odchyłki występującej w punkcie styku końcówki pomiarowej z powierzchnią mierzonego elementu (punkt $S_{1}$ na rys. 4) oraz odchyłki w punktach styku mierzonego obiektu z pryzmą pomiarową (punkty $S_{2}$ i $S_{3}$ na rys. 4). W metodzie odniesieniowej faktyczną wielkością mierzoną jest odległość $z$ na rys. 4.

Brak możliwości bezpośredniego uzyskania zarysu rzeczywistego był znacznym ograniczeniem użyteczności metody odniesieniowej w ujęciu tradycyjnym, gdyż należało znać dominujące rodzaje błędów kształtu mierzonego przedmiotu. Dlatego wprowadzono współczynnik wykrywalności $K_{n}$, będący funkcją matematyczną parametrów metody odniesieniowej. Znając dominującą składową błędu kształtu i używając współczynnika $K_{n}$, można wyznaczyć przybliżoną wartość odchyłki okrągłości $\Delta Z$. Korzysta się z zależności:

$$
\Delta Z \cong \frac{\Delta F}{K_{n}}
$$

gdzie: $\Delta F$ - zarys okrągłości zmierzony czujnikiem pomiarowym.

Podsumowując, współczynnik wykrywalności $K_{n}$ jest funkcją parametrów metody, tj. kątów $\alpha$ i $\beta$ oraz liczby $n$, która określa dla zarysów regularnych tzw. n-graniastość. Współczynnik ten określa się zależnością:

$$
K_{n}(\alpha, \beta)=\frac{C_{\mathrm{F} n}}{C_{\mathrm{R} n}}
$$

gdzie: $C_{F n}$ - amplituda $n$-harmonicznej zarysu zmierzonego, $C_{R n}$ - amplituda $n$-harmonicznej zarysu rzeczywistego.

W ostatnich latach dzięki przeanalizowaniu błędów metody odniesieniowej opracowano modele matematyczne, których zadaniem było zwiększenie dokładności tej metody. Jeśli zastosuje się odpowiedni model matematyczny oraz oprogramowanie komputerowe, można z powodzeniem wykorzystać metody odniesieniowe do oceny odchyłki okrągłości oraz walcowości. 


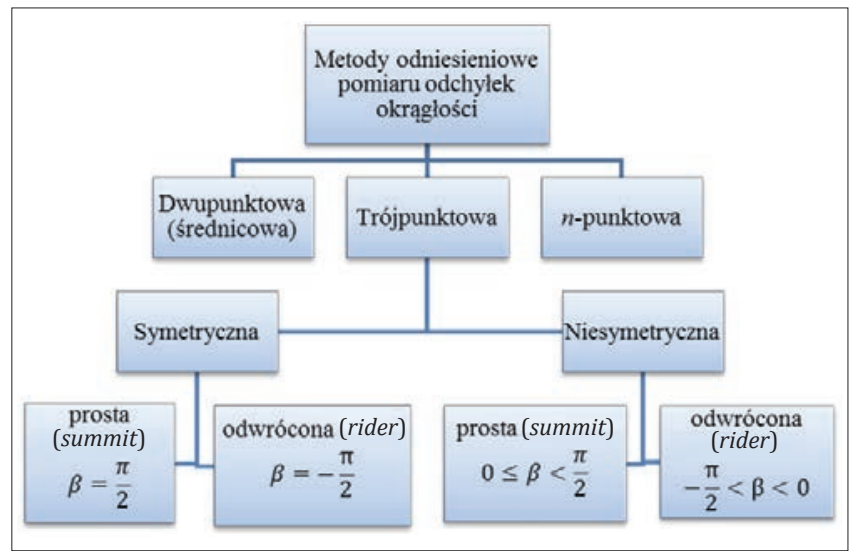

Fig. 6. Types of datum-based methods for measuring roundness deviations in the $\beta$ angle range: $-\frac{\pi}{2} \leq \beta \leq \frac{\pi}{2}[8]$

Rys. 6. Odmiany metod odniesieniowych do pomiaru odchyłek okrągłości w zakresie kątów $\beta$ : $-\frac{\pi}{2} \leq \beta \leq \frac{\pi}{2}$ [8]

Norma PN-93/M-04261 przedstawia terminologię oraz szczegółowy podział metody odniesieniowej służącej do oceny zarysów okrągłości. W zależności od parametrów metody odniesieniowej - tj. liczby punktów pomiarowych oraz podparcia, wartości kąta określającego rozwarcie pryzmy pomiarowej oraz kąta określającego położenia czujnika pomiarowego - metody odniesieniowe można podzielić według schematu pokazanego na rys. 6.

Pomiar dwupunktowy jest to pomiar między współosiowymi końcówkami pomiarowymi, z których jedna jest stała, a druga przesuwna w kierunku pomiaru. Metoda dwupunktowa jest najstarszą metodą odniesieniową. Powszechnie stosuje się ją w warunkach przemysłowych ze względu na prostotę, gdyż wymaga jedynie płyty pomiarowej oraz czujnika pomiarowego. Natomiast jej wadą jest ograniczenie zastosowania do pomiaru zarysów okrągłości określonych parzystą liczbą $n$ fal cosinusowych. Na rys. 7 przedstawiono pomiar dwupunktowy realizowany metodą klasyczną, gdzie: $\alpha=\pi, \beta=\frac{\pi}{2}$.

Pomiar trójpunktowy jest to pomiar między końcówkami pomiarowymi, z których dwie są stałe

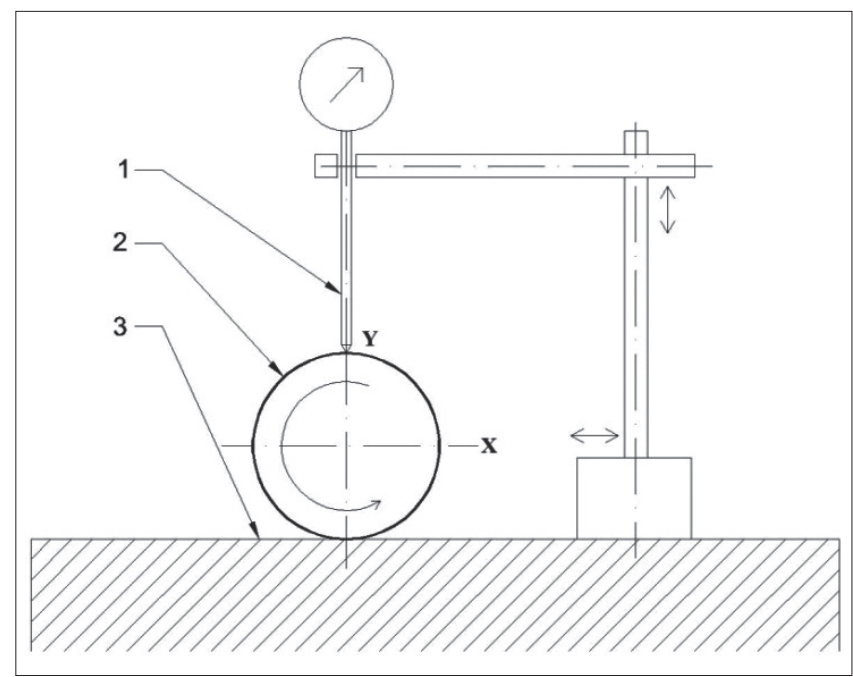

Fig. 7. Two-point method: 1 - measuring sensor, 2 - measured object, 3 - measuring plate

Rys. 7. Metoda dwupunktowa: 1 - czujnik pomiarowy, 2 - mierzony przedmiot, 3 - płyta pomiarowa

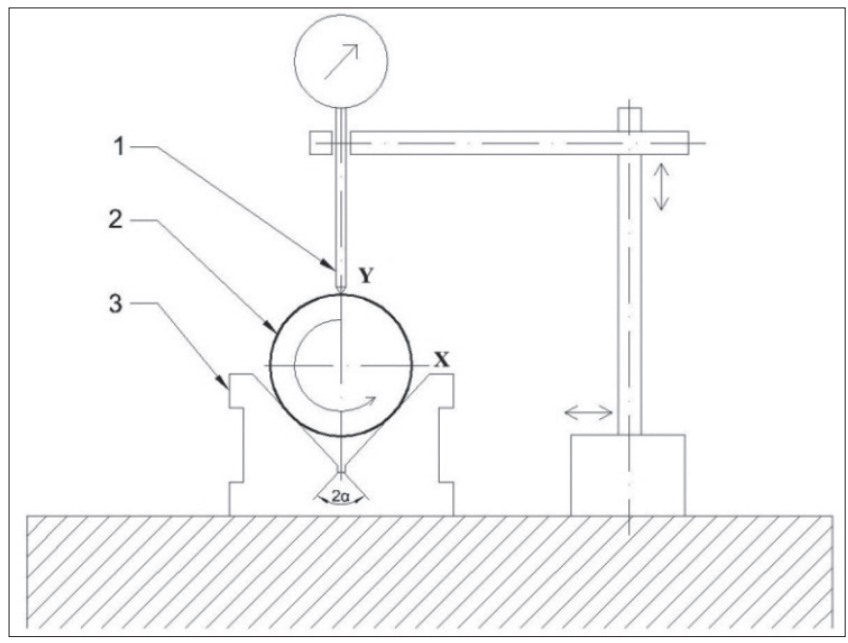

Fig. 8. Three-point symmetrical simple method: 1 - measuring sensor, 2 - measured object, 3 - measuring prism

Rys. 8. Metoda trójpunktowa symetryczna prosta: 1 - czujnik pomiarowy, 2 - mierzony przedmiot, 3 - pryzma pomiarowa

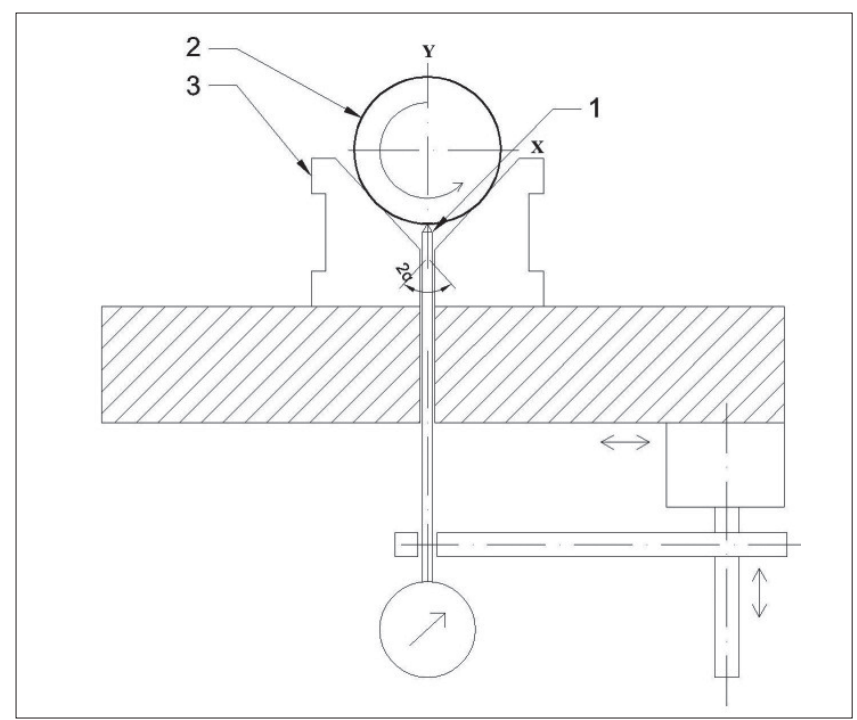

Fig. 9. Three-point inverted symmetrical method: 1 - measuring sensor, 2 - measured object, 3 - measuring prism

Rys. 9. Metoda trójpunktowa symetryczna odwrócona: 1 - czujnik pomiarowy, 2 - mierzony przedmiot, 3 - pryzma pomiarowa

(pryzma pomiarowa), a trzecia przesuwa się w kierunku pomiaru. Metody trójpunktowe można podzielić na symetryczne i niesymetryczne. Symetryczne metody trójpunktowe są realizowane $\mathrm{w}$ dwóch wersjach: prostej $\left(\beta=\frac{\pi}{2}\right.$; rys. 8) oraz odwróconej $\left(\beta=-\frac{\pi}{2}\right.$; rys. 9). Najprościej jest wykonać pomiar metodą trójpunktową symetryczną z użyciem tradycyjnej pryzmy pomiarowej oraz czujnika pomiarowego. Niestety w wielu przypadkach nie można ocenić zarysów okrągłości określonych parzystą liczbą $n$ fal cosinusowych, co znacznie zmniejsza dokładność pomiaru.

Niedogodności te wyeliminowało wprowadzenie niesymetrycznej metody trójpunktowej, którą można podzielić na prostą $\left(0 \leq \beta<\frac{\pi}{2}\right.$; rys. 10) oraz odwróconą $\left(-\frac{\pi}{2}<\beta<0\right.$; rys. 11). Dużą jej zaletą jest to, że pozwala wykryć nieparzystą oraz parzystą liczbę fal cosinusowych. Przy czym należy uwzględnić odpowiedni wybór parametrów metody odniesieniowej, czyli wartości kątów $\alpha$ oraz $\beta$. W celu wykrycia różnych odchyłek należy tak dobrać parametry metody 


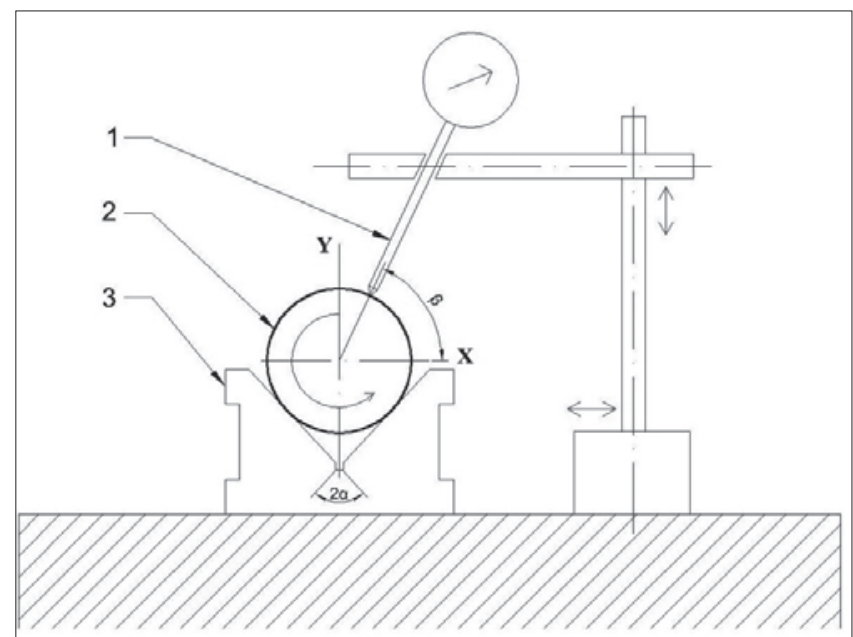

Fig. 10. Three-point asymmetrical straight method: 1 - measuring sensor, 2 - measured object, 3 - measuring prism

Rys. 10. Metoda trójpunktowa niesymetryczna prosta: 1 - czujnik pomiarowy, 2 - mierzony przedmiot, 3 - pryzma pomiarowa

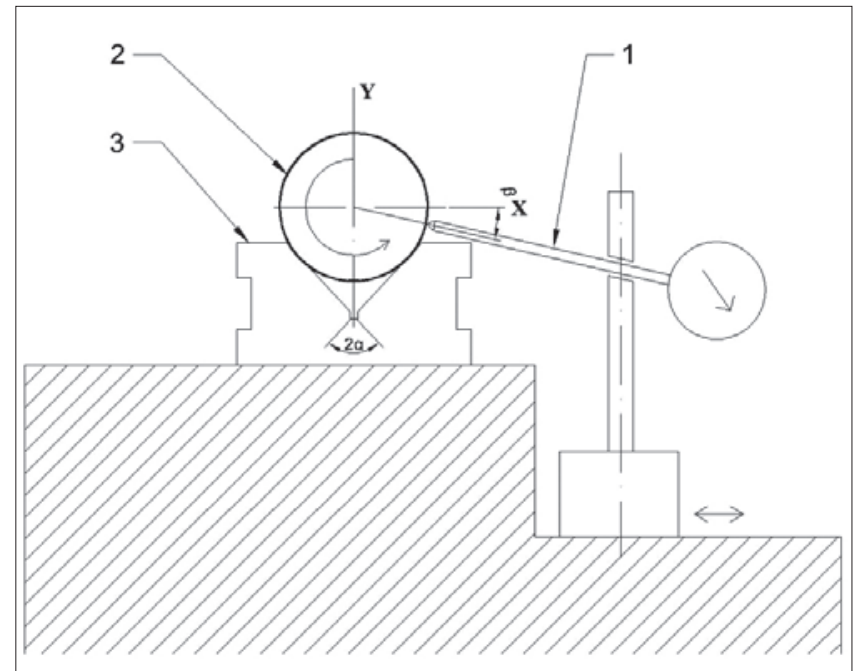

Fig. 11. Asymmetrical inverted three-point method: 1 - measuring sensor, 2 - measured object, 3 - measuring prism

Rys. 11. Metoda trójpunktowa niesymetryczna odwrócona: 1 - czujnik pomiarowy, 2 - mierzony przedmiot, 3 - pryzma pomiarowa

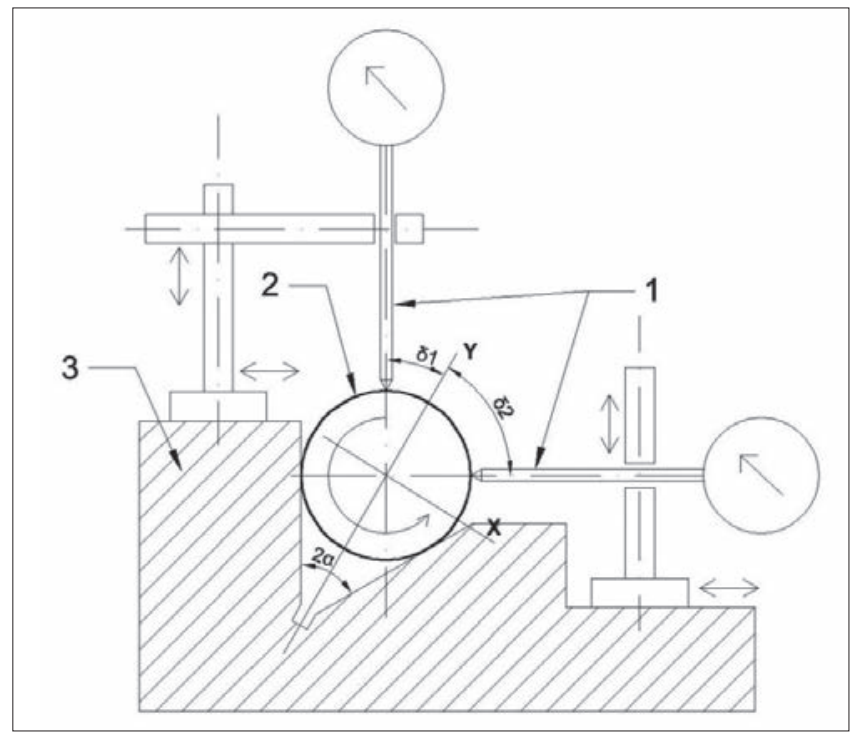

Fig. 12. Multi-point method: 1 - measuring sensors, 2 - measured object, 3 - measuring prism, $\delta 1, \delta 2$ - auxiliary angles

Rys. 12. Metoda wielopunktowa: 1 - czujniki pomiarowe, 2 - mierzony przedmiot, 3 - pryzma pomiarowa, $\delta 1, \delta 2$ - kąty pomocnicze odniesieniowej, aby współczynniki wykrywalności $K_{n}$ w określonym zakresie nie zerowały się. Wybór odpowiednich parametrów metody odniesieniowej pozwala w znacznym stopniu zwiększyć jej dokładność pomiarową.

Kolejną grupą metod odniesieniowych są metody $n$-punktowe, zwane również wielopunktowymi. Pomiar zarysu okrągłości można $\mathrm{w}$ tym przypadku wykonać z zastosowaniem tradycyjnej pryzmy pomiarowej oraz kilku czujników pomiarowych (rys. 12) lub $\mathrm{z}$ zastosowaniem specjalnej pryzmy z samonastawnymi podporami. Jedną z głównych zalet metody wielopunktowej jest wyeliminowanie obrotu mierzonego przedmiotu oraz przemieszczania się jego środka, co znacznie zwiększa dokładność pomiarową. Natomiast wadą jest wyższy koszt urządzenia pomiarowego z powodu wprowadzenia specjalnych pryzm lub kilku czujników pomiarowych.

\section{Wspótrzędnościowa technika pomiarowa}

W ostatnich latach współrzędnościowe techniki pomiarowe dynamicznie rozwijają się $\mathrm{w}$ obszarze pomiaru zarysu okrągłości. Pomiar taki może być realizowany za pomocą WMP (współrzędnościowej maszyny pomiarowej), której schemat przedstawiono na rys. 13.

Jedną z głównych zalet zastosowania WMP jest możliwość kompleksowego mierzenia wymiarów, odchyłek kształtu i położenia na jednym urządzeniu, w jednym cyklu kontrolnym CNC, co ma duże znaczenie zwłaszcza w warunkach przemysłowych, gdzie należy skracać czas pomiaru. W przypadku wąskich pól tolerancji lub nastawienia produkcji na jeden typ elementu preferowane są urządzenia specjalizowane, natomiast przy pomiarach złożonych elementów z powodzeniem można stosować współrzędnościowe maszyny pomiarowe.

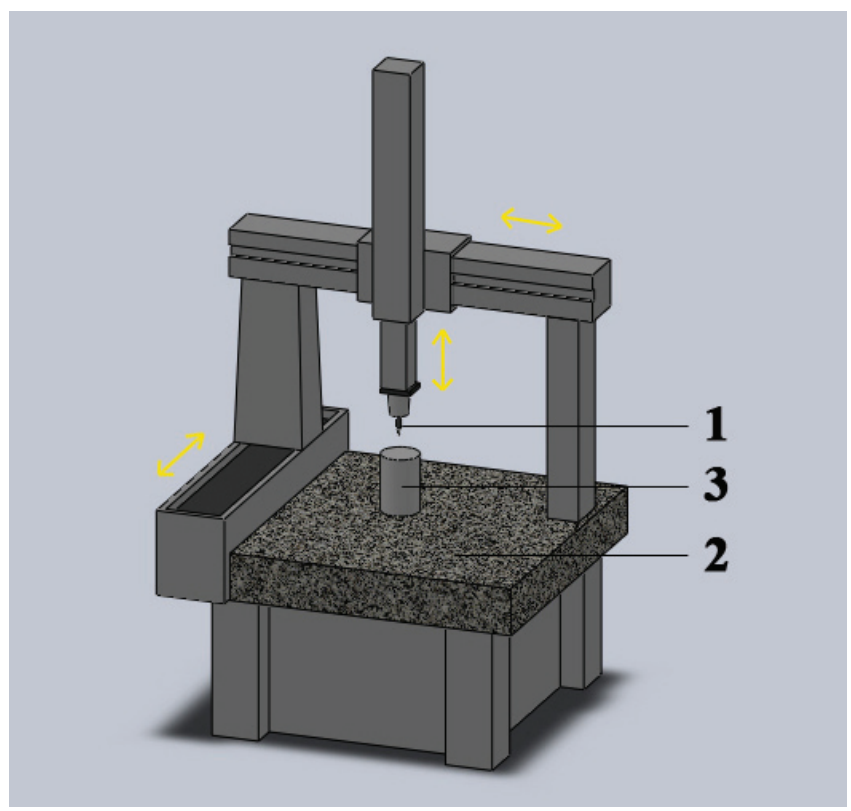

Fig. 13. Coordinate measuring machine: 1 - measuring sensor, 2 - measuring table, 3 - measured object

Rys. 13. Współrzędnościowa maszyna pomiarowa: 1 - czujnik pomiarowy, 2 - stolik pomiarowy, 3 - mierzony przedmiot 
Do pomiarów współrzędnościowych stosuje się głowice impulsowe, a ostatnio coraz bardziej popularne są głowice skaningowe. W przypadku pomiaru wykonywanego głowicami impulsowymi podstawowym problemem jest wybór optymalnej liczby punktów pomiarowych, gdyż od tego zależą błąd wyznaczenia okręgu skojarzonego oraz błąd oceny zarysu okrągłości. Czas pomiaru głowicą impulsową jest dłuższy. Natomiast wprowadzenie sond skanujących pozwoliło zwiększyć dokładność pomiaru odchyłki okrągłości na WMP. Charakterystyczną cechą jest to, że głowica skaningowa, mająca sześć stopni swobody, musi mieć co najmniej trzy przetworniki indukcyjne, inkrementalne lub optyczne. Sygnał z takich przetworników jest przekształcany na postać cyfrową i dalej przetwarzany, co powoduje powstawanie szumów pomiarowych i wpływa na wynik końcowy.

Kolejnym ograniczeniem stosowania WMP do oceny odchyłek okrągłości jest prędkość pomiarowa głowicy skanującej. Badania wykazały, że przy wzroście tej prędkości $>20 \mathrm{~mm} / \mathrm{s}$ dokładność oceny odchyłki okrągłości zmniejsza się. Jest to związane przede wszystkim ze sztywnością ruchomej części WMP i rodzajem użytej głowicy pomiarowej oraz jej końcówek.

Badania eksperymentalne, mające na celu ocenę dokładności pomiaru odchyłki okrągłości na WMP, wykazały, że względna dokładność pomiaru zarysów okragłości na współrzędnościowej maszynie pomiarowej Eclipse 550 w porównaniu z pomiarami wykonanymi na wzorcowym przyrządzie pomiarowym Talyrond 73 wyniosła $D M=17,2 \%$.

Chociaż WMP nadają się do oceny odchyłek okrągłości, jednak istnieją pewne ograniczenia stosowalności tych urządzeń do pomiaru falistości powierzchni cylindrycznych w zakresie powyżej 15 fal/obrót.

Ciekawym rozwiązaniem wydawać się może zastosowanie ramion pomiarowych do oceny odchyłek okrągłości dużych elementów cylindrycznych, lecz ich dokładność jest wciąż ograniczona.

Podsumowując, ciągły rozwój oraz udoskonalanie konstrukcji urządzeń pomiarowych opartych na technice współrzędnościowej pozwalają na wystarczającą ocenę zarysów okrągłości $\mathrm{w}$ warunkach przemysłowych, bez konieczności stosowania drogich przyrządów specjalistycznych, wykorzystujacych metodę promieniowa z obrotowym czujnikiem lub stolikiem, która można stosować jedynie do oceny odchyłek okrągłości, walcowości oraz prostoliniowości. Jednakże przyrządy pomiarowe oparte na współrzędnościowej technice pomiarowej są stosunkowo drogie, a ich obsługa jest skomplikowana i wymaga zatrudnienia wykwalifikowanego personelu. Należy dodać, że WMP nie nadają się do pomiaru odchyłki okrągłości lub falistości dużych elementów cylindrycznych zamocowanych bezpośrednio w uchwycie obrabiarki, co w znaczny sposób ogranicza ich możliwości pomiarowe $w$ warunkach produkcyjnych, przede wszystkim w przemyśle ciężkim.

\section{Pomiar zarysów okrągłości}

Na Politechnice Świętokrzyskiej w Kielcach prowadzone są badania nad zastosowaniem metody odnie- sieniowej do oceny zarysów okrągłych części maszyn. Przeprowadzono również modernizację oraz komputeryzację przyrządów pomiarowych bazujących na metodzie promieniowej, służących do oceny odchyłek okrągłości oraz walcowości. Dzięki komputeryzacji przyrząu pomiarowego Talyrond 200 osiagnięto dokładność pomiaru odchyłki okrągłości $D M=6,7 \%$, podczas gdy dokładność tego przyrządu w wersji tradycyjnej wynosiła $D M=22,4 \%$. Przy ocenie dokładności pomiaru za przyrząd wzorcowy uznano Talyrond 73

Prace eksperymentalne potwierdziły nieprzydatność tradycyjnej metody odniesieniowej do dokładnej oceny zarysów okrągłości, gdyż uzyskana względna dokładność metody znajduje się w przedziale $22 \div 63 \%$ (patrz tabl. I).

TABLE I. Results of statistical experimental studies of the method error for measuring roundness deviations by the traditional datum-based method [8]

TABLICA I. Wyniki statystycznych badań eksperymentalnych błędu metody dla pomiarów odchyłki okrągłości tradycyjną metodą odniesieniową [8]

\begin{tabular}{|l|c|c|c|}
\hline \multicolumn{1}{|c|}{$\begin{array}{c}\text { Nazwa próbki } \\
\text { (rodzaj obróbki) }\end{array}$} & Toczenie & $\begin{array}{c}\text { Szlifowa- } \\
\text { nie } \\
\text { zgrubne }\end{array}$ & $\begin{array}{c}\text { Szlifo- } \\
\text { wanie } \\
\text { wykończe- } \\
\text { niowe }\end{array}$ \\
\hline $\begin{array}{l}\text { Wartość średnia błędów } \\
\text { metody, } \bar{W}_{\Delta \mathrm{R}}\end{array}$ & $-0,019 \mu \mathrm{m}$ & $0,021 \mu \mathrm{m}$ & $0,074 \mu \mathrm{m}$ \\
\hline Odchylenie średnie, $s$ & $0,098 \mu \mathrm{m}$ & $0,144 \mu \mathrm{m}$ & $0,279 \mu \mathrm{m}$ \\
\hline $\begin{array}{l}\text { Przedział ufności dla } \\
\text { pojedynczego błędu } \\
\text { metody }\end{array}$ & $\begin{array}{c}0,019 \\
\pm 0,196 \mu \mathrm{m}\end{array}$ & $\begin{array}{c}0,021 \\
\pm 0,288 \mu \mathrm{m}\end{array}$ & $\begin{array}{c}0,074 \\
\pm 0,558 \mu \mathrm{m}\end{array}$ \\
\hline Dokładność metody, $D M$ & $21,5 \%$ & $30,9 \%$ & $63,2 \%$ \\
\hline
\end{tabular}

Badania eksperymentalne prowadzono na trzech grupach próbek, liczących po 50 sztuk. Każda grupa została poddana innej operacji obróbki skrawaniem, tj. obróbce tokarskiej, szlifowaniu zgrubnemu i szlifowaniu wykończeniowemu. Największą wartość średnią błędów metody $\bar{W}_{\Delta \mathrm{R}}=0,074$ uzyskano dla próbek poddanych szlifowaniu wykończeniowemu, natomiast najmniejszą wartość średnią błędów metody $\bar{W}_{\Delta \mathrm{R}}=-0,019$ - dla próbek toczonych. To potwierdza, że tradycyjna metoda odniesieniowa - mimo że $\mathrm{w}$ pewnym stopniu może być przydatna do oceny odchyłek okrągłości większej wartości - w przypadku elementów poddanych obróbce szlifierskiej, gdzie wartości odchyłek okrągłości są niskie, nie może być stosowana. Ograniczeniem tradycyjnej metody odniesieniowej była niemożliwość wykonania dokładnego pomiaru odchyłki okrągłości przy nieznanym zarysie okrągłości. Pomiar taki traktowany był jako szacunkowy. Natomiast w przypadku posiadania informacji o zarysie okrągłości uwzględniano jedynie współczynniki wykrywalności pochodzące od dominującej składowej harmonicznej, co wpływało na dokładność pomiaru. Również stosowanie współczynnika wykrywalności jest znacznie utrudnione, czasochłonne i może powodować powstawanie dodatkowych błędów.

Na podstawie przeprowadzonych badań oraz analizy wszystkich błędów metody opracowano model matematyczny oparty na rozwinięciu zarysu okrągłości 
w szereg Fouriera. Model ten wykorzystano w procedurach komputerowych, by przeprowadzić komputerową transformację zarysu zmierzonego $F(\varphi)$ na zarys przetworzony $R_{\mathrm{p}}(\varphi)$, odpowiadający zarysowi rzeczywistemu $R(\varphi)$. Opracowanie modelu matematycznego oraz procedur komputerowych pozwoliło na eliminację oraz minimalizację wspomnianych błędów metody tradycyjnej i przystosowanie metody odniesieniowej do dokładnych pomiarów odchyłki okrągłości realizowanych $\mathrm{w}$ warunkach przemysłowych. $\mathrm{W}$ wyniku przeprowadzonych zabiegów uzyskano dokładność metody w przedziale $D M=13 \div 15 \%$ (patrz tabl. II).

Table II. Results of statistical experimental research of the method error for measuring the roundness deviation by a computerized datum-based method [8]

TABLICA II. Wyniki statystycznych badań eksperymentalnych błędu metody dla pomiarów odchyłki okrągłości skomputeryzowaną metodą odniesieniową [8]

\begin{tabular}{|l|c|c|c|}
\hline \multicolumn{1}{|c|}{$\begin{array}{c}\text { Nazwa próbki } \\
\text { (rodzaj obróbki) }\end{array}$} & Toczenie & $\begin{array}{c}\text { Szlifowa- } \\
\text { nie } \\
\text { zgrubne }\end{array}$ & $\begin{array}{c}\text { Szlifowa- } \\
\text { nie wykoń- } \\
\text { czeniowe }\end{array}$ \\
\hline $\begin{array}{l}\text { Wartość średnia błę- } \\
\text { dów metody, } \bar{W}_{\Delta \mathrm{R}}\end{array}$ & $0,06 \mu \mathrm{m}$ & $0,055 \mu \mathrm{m}$ & $0,041 \mu \mathrm{m}$ \\
\hline Odchylenie średnie, $s$ & $0,034 \mu \mathrm{m}$ & $0,045 \mu \mathrm{m}$ & $0,051 \mu \mathrm{m}$ \\
\hline $\begin{array}{l}\text { Przedział ufności dla } \\
\text { pojedynczego błędu } \\
\text { metody }\end{array}$ & $\begin{array}{c}0,060 \\
\pm 0,068 \mu \mathrm{m}\end{array}$ & $\begin{array}{c}0,055 \\
\pm 0,090 \mu \mathrm{m}\end{array}$ & $\begin{array}{c}0,041 \\
\pm 0,102 \mu \mathrm{m}\end{array}$ \\
\hline Dokładność metody, $D M$ & $12,8 \%$ & $14,5 \%$ & $14,3 \%$ \\
\hline
\end{tabular}

Na podstawie wyników badań statystycznych przedstawionych w tabl. II można stwierdzić, że metoda odniesieniowa z użyciem odpowiedniego modelu matematycznego oraz procedur komputerowych może być wykorzystana do dokładnych pomiarów odchyłek okragłości w warunkach przemysłowych. W wyniku badań została opracowana głowica pomiarowa MUK do pomiaru odchyłek okrągłości elementów walcowych zamocowanych bezpośrednio na obrabiarce. Głowica ta została wdrożona w wielu zakładach przemysłowych oraz ośrodkach badawczych w kraju i za granicą. Na rys. 14 pokazano pomiar zarysu kształtu czopa głównego wału korbowego bezpośrednio na obrabiarce, z użyciem głowicy MUK.

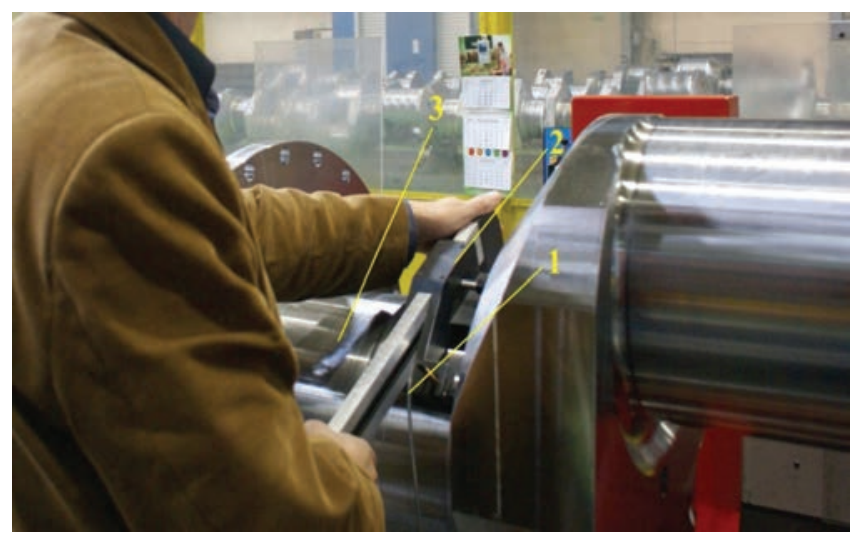

Fig. 14. MUK head for measuring out-of-roundness of large machine parts: 1 - inductive sensor, 2 - measuring head, 3 - measured object (crankshaft journ) [8]

Rys. 14. Głowica MUK do pomiaru zarysów okragłości dużych części maszyn: 1 - czujnik indukcyjny, 2 - głowica pomiarowa, 3 - mierzony przedmiot (czop wału korbowego) [8]

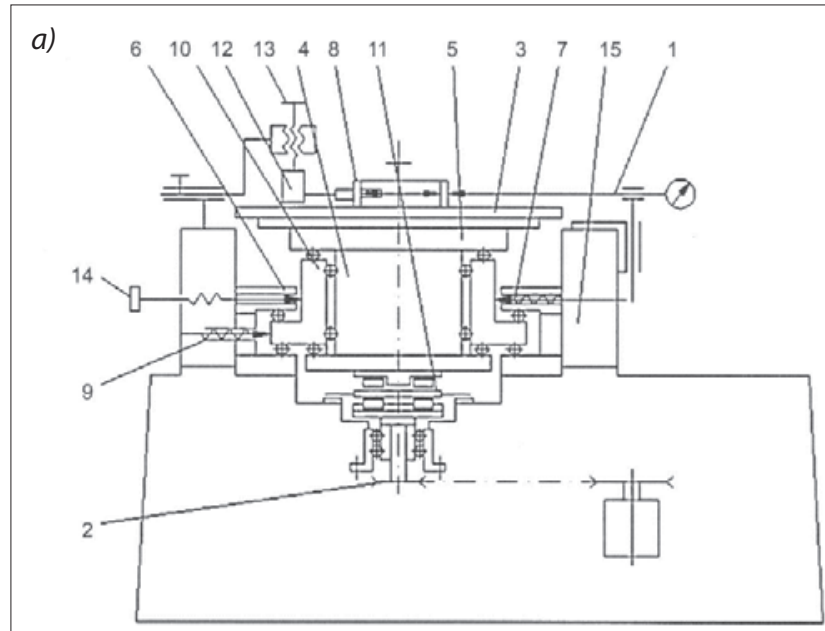

12

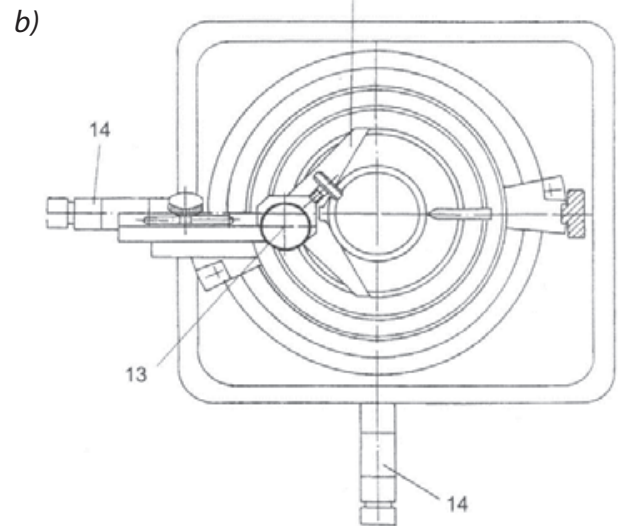

Fig. 15. Diagram of the PSA 4 device for measuring out-of-roundness by datum-based methods: $a$ ) cross-section, $b$ ) top view of the measuring table [8]

Rys. 15. Schemat przyrządu PSA 4 do pomiarów zarysów okrąłłości metodami odniesieniowymi: a) przekrój poprzeczny, b) widok z góry stolika pomiarowego [8]

Kolejnym rozwiązaniem opracowanym we współpracy z Politechniką Świętokrzyską jest przyrząd PSA 4 (rys. 15). Wykorzystuje on metodę bezodniesieniową z obrotowym stołem i dowolną metodę odniesieniową. Taka konstrukcja zapewnia bardziej precyzyjny pomiar.

Przyrząd PSA4 jest zbudowany z zespołu pomiarowego wyposażonego w czujnik (1) i zespół napędowy (2) oraz stolika pomiarowego (3) z tuleją (4), która z zamocowanym na jej górnej płaszczyźnie zespołem stolika pomiarowego jest pionowo ułożyskowana w pierścieniu z kołnierzem. Wraz z nim tuleja przemieszcza się w płaszczyźnie poziomej za pomocą dwóch usytuowanych prostopadle względem siebie pryzm nożowych (6). Pryzmy te sa stale dociskane do pierścienia z kołnierzem i ograniczają trzy zespoły rozmieszczone na obwodzie korpusu (9). Tuleja jest ułożyskowana za pomocą zespołu tocznego (10). Jest ona połączona z zespołem napędowym sprzęgłem tarczowym (11). W górnej części korpusu jest umocowany zespół stałych punktów podparcia (13), a w płaszczyźnie poziomej są dwa pokrętła (14). Na obwodzie górnej części korpusu znajduje się prowadnica pierścieniowa, po której przemieszczają się zespoły pomiarowe czujnika (1) w kierunku pionowym i poziomym, za pomocą pokrętła i śruby. 


\section{Pomiar zarysów walcowości}

Na Politechnice Świętokrzyskiej prowadzone były również prace badawcze mające na celu zastosowanie metody odniesieniowej do pomiaru walcowości powierzchni cylindrycznych $\mathrm{w}$ warunkach produkcyjnych. Opracowano stanowisko badawcze PSA6 (rys. 16), składające się z dwóch połączonych zestawów pryzm pomiarowych (4) oraz dokładnie wykonanej prowadnicy (2), po której przemieszcza się czujnik indukcyjny (6).

Pomiar wykonywany za pomocą przyrządu PSA6 jest zautomatyzowany i kontrolowany za pośrednictwem sterownika komputerowego. Można dowolnie sterować położeniem czujnika pomiarowego oraz kątem obrotu mierzonego przedmiotu, by zeskanować powierzchnię walcową. Badania eksperymentalne, polegające na porównaniu wyników pomiarów odchyłki walcowości wykonanych z użyciem stanowiska PSA6, opartego na metodzie odniesieniowej, oraz urządzenia Talycenta, opartego na metodzie bezodniesieniowej, pozwoliły stwierdzić, że względny błąd wyznaczenia odchyłki walcowości wynosi $W_{\text {CYLt }}=9,2 \%$.

Po analizie oraz eliminacji potencjalnych źródeł błędów metody odniesieniowej, służącej do pomia-

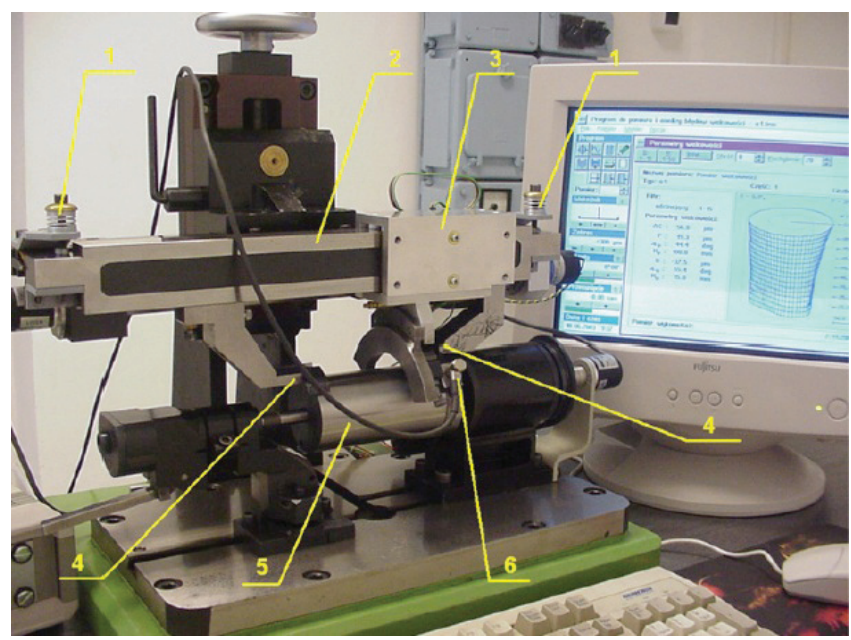

Fig. 16. Model test stand for datum-based measurements of out-of-cylindricity: 1 - spring system, 2 - guide, 3 - carriage, 4 - measuring prisms, 5 - measured object, 6 - inductive sensor [9]

Rys. 16. Modelowe stanowisko badawcze służące do odniesieniowych pomiarów odchyłki walcowości: 1 - system sprężyn, 2 - prowadnica, 3 - suport, 4 - pryzmy pomiarowe, 5 - mierzony przedmiot, 6- czujnik indukcyjny [9]

TABLE III. The results of statistical experimental research of the method error for measuring cylindrical deviation by the reference method

TABLICA III. Wyniki statystycznych badań eksperymentalnych błędu metody dla pomiarów odchyłki walcowości metodą odniesieniową

\begin{tabular}{|c|c|}
\hline Liczba próbek & 50 \\
\hline Wartość średnia błędów metody, $W_{\text {CYLt }}$ & $0,04 \mu \mathrm{m}$ \\
\hline Odchylenie średnie, $s$ & $0,074 \mu \mathrm{m}$ \\
\hline Dokładność metody, $D M$ & $19,4 \%$ \\
\hline
\end{tabular}

ru odchyłki walcowości (różnica kątów pryzm bazowych, ograniczona kalibracja czujnika pomiarowego, pochylenie prowadnicy przyrządu w płaszczyźnie wyznaczonej przez oś i kierunek przesuwu czujnika pomiarowego), uzyskano względny błąd wyznaczenia odchyłki walcowości $W_{\text {CYLt }}=6,2 \%$. Szczegółowe badania statystyczne pozwoliły wyznaczyć dokładność tej metody na poziomie $D M=19,4 \%$ (patrz. tabl. III), z czego można wyciągnąć wniosek, że metoda odniesieniowa może być użyta do oceny odchyłki walcowości w warunkach przemysłowych.

\section{Pomiar falistości powierzchni}

Na podstawie analizy błędów kształtu powierzchni obrotowych zarys zmierzony powinien zostać poddany odpowiedniej filtracji, zgodnie z normą PN-EN 12181-1:2003. Każdy zmierzony zarys elementu cylindrycznego zawiera pewną liczbę pełnych okresowych fal, przedstawionych jako UPR (ang. undulation per revolution). Odpowiedni filtr pozwala usunąć niepożądane informacje o zarysie zmierzonym powyżej lub poniżej określonej częstotliwości. W praktyce pomiarowej stosuje się filtry: dwubiegunowy z korekcją i bez korekcji fazy, odcinający (Fouriera) i Gaussa. W zależności od wyboru rodzaju filtra wartości wyznaczonej odchyłki okrągłości mogą się różnić. Każdy rodzaj filtra ma bowiem różne charakterystyki przenoszenia, które podają wartość, o jaką jest tłumiona amplituda profilu sinusoidalnego $\mathrm{w}$ zależności od długości fali. Dzięki zastosowaniu odpowiedniego filtra oraz ustaleniu jego pasma przenoszenia można usunąć z zarysu zmierzonego składowe okrągłości i pozostawić jedynie potrzebne składowe falistości powierzchni cylindrycznych.

Rozpatrując odchyłki kształtu powierzchni cylindrycznych przyjęto, że okrągłość występuje w zakresie 2-15UPR, natomiast falistość - w zakresie 15-500UPR. W metodzie odniesieniowej falistość należy badać w zakresie 16-50UPR, ponieważ ocena falistości powyżej 50UPR jest mało wiarygodna.

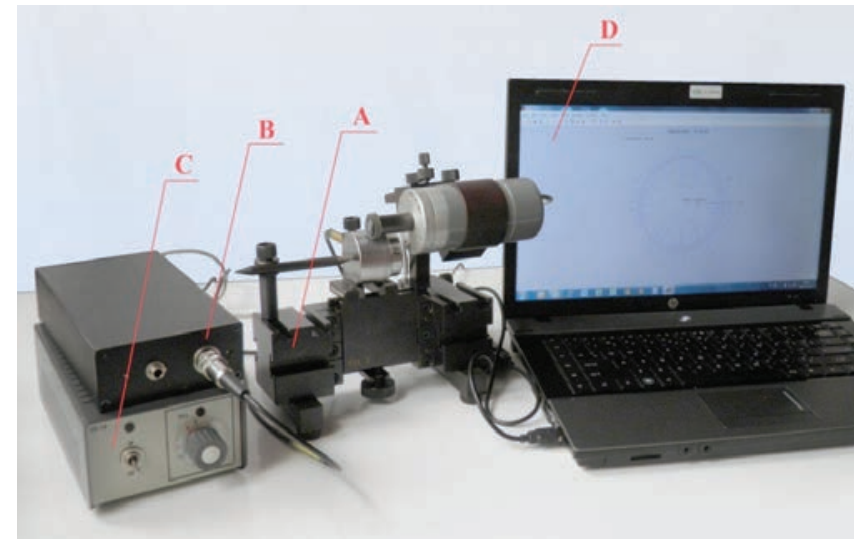

Fig. 17. Model test stand for datum-based measurements of surface waviness: $A-\mathrm{ROL}-2$ measuring instrument, $B$ - measurement control system, $C$ - electronic drive system of the guide disc, $D$ - portable computer

Rys. 17. Modelowe stanowisko badawcze do odniesieniowych pomiarów falistości powierzchni: $A$ - przyrząd pomiarowy ROL-2, $B$ - system sterowania pomiarem, $C$ - elektroniczny system napędowy tarczy prowadzącej, $D$ - komputer przenośny 
W celu weryfikacji koncepcji zastosowano metody odniesieniowe do pomiaru falistości powierzchni cylindrycznych. Opracowano modelowe stanowisko badawcze (rys. 17). W jego skład wchodzą: przyrząd pomiarowy ROL-2 $(A)$, opracowany przez czeską firmę Mdra-Brno, system sterowania pomiarem $(B)$, elektroniczny system napędowy tarczy prowadzącej $(C)$ oraz przenośny komputer $(D)$.

Komputer wykorzystany do realizacji pomiarów został wyposażony w oprogramowanie SAJD do rejestrowania sygnału z czujnika pomiarowego oraz dodatkowych procedur opracowanych w języku oprogramowania Matlab, służących do transformacji zarysu zmierzonego czujnikiem pomiarowym $F(\varphi)$ na zarys przetworzony $R_{\mathrm{p}}(\varphi)$ i pozwalających na analizę danych pomiarowych. Głównym zastosowaniem przyrządu ROL-2 jest ocena odchyłki okrągłości oraz falistości wałeczków łożysk tocznych.
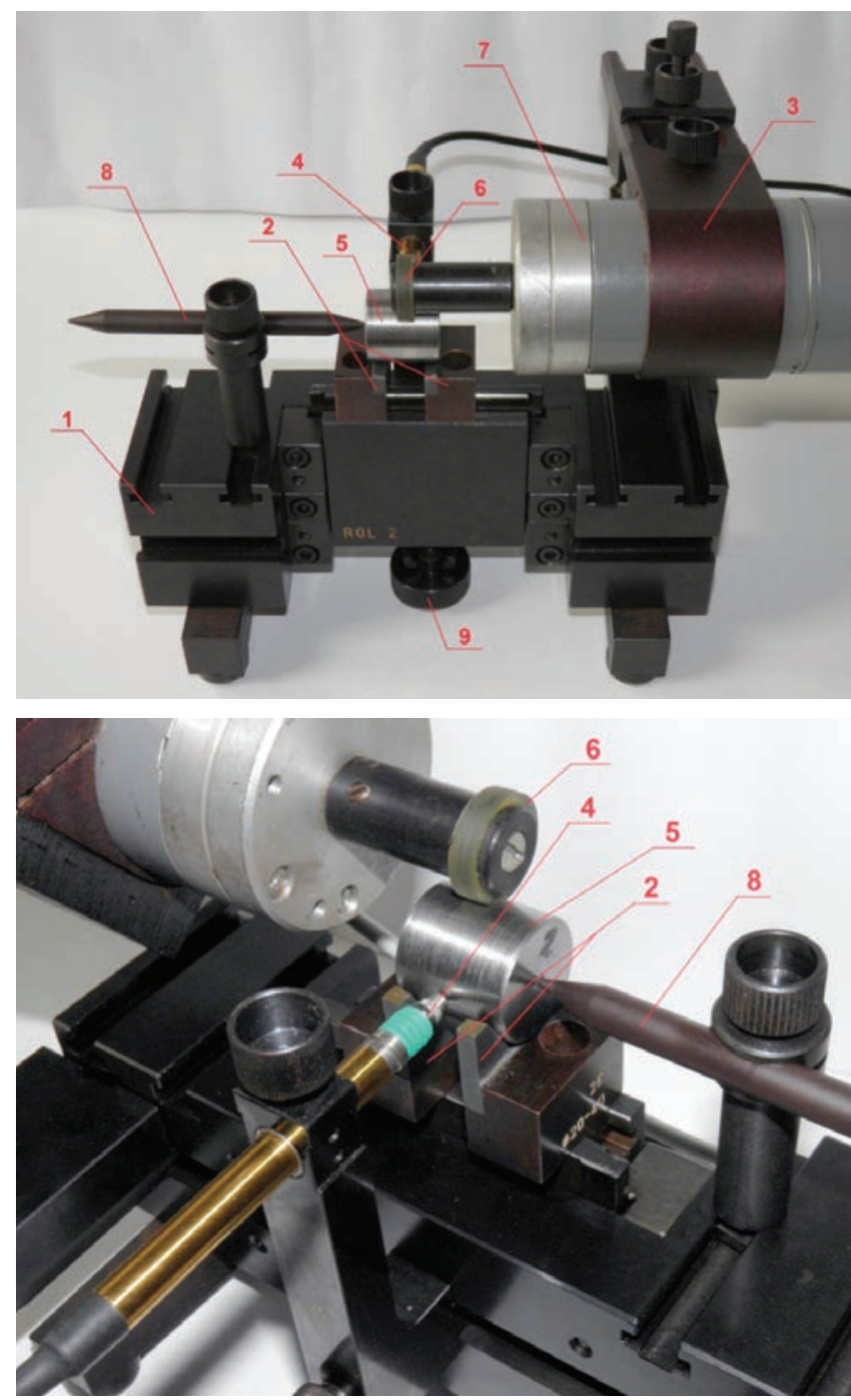

Fig. 18. ROL-2 measuring device included in the model test stand for datum-based measurements of surface waviness: 1 - body, 2 - measuring prisms, 3 - drive system, 4 - inductive sensor, 5 - measured object, 6 - driving disk, 7 - electric motor, 8 - bracket, 9 - screw adjusting the height of the prism

Rys. 18. Przyrząd pomiarowy ROL-2 wchodzący w skład modelowego stanowiska badawczego do odniesieniowych pomiarów falistości powierzchni: 1 - korpus, 2 - pryzmy pomiarowe, 3 - układ napędowy, 4 - czujnik indukcyjny, 5 - mierzony przedmiot, 6 - tarcza napędzająca, 7 - silnik elektryczny, 8 - wspornik, 9 - śruba regulująca wysokość pryzm
Na rys. 18 przedstawiono przyrząd pomiarowy ROL-2. Składa się on z korpusu (1), na którym umieszczone są pryzmy pomiarowe (2), system napędowy (3) oraz czujnik indukcyjny (4).

W rozpatrywanym przyrządzie pomiarowym ROL-2 mierzony wałek (5) jest umieszczony na dwóch pryzmach nożowych (1). Jedna z nich pełni funkcję pryzmy pomiarowej, natomiast druga ma funkcję podtrzymującą. Mierzony wałek jest wprawiany w ruch obrotowy za pośrednictwem tarczy (6) napędzanej przez silnik elektryczny (7). By zapewnić lepszy styk tarczy napędzającej (6) z przedmiotem mierzonym (5), tarcza pokryta jest gumą. Dodatkowym zadaniem tarczy prowadzącej jest zapewnienie stałego docisku mierzonego przedmiotu (5) do pryzmy pomiarowej (2). Odpowiednie ustawienie mierzonego przedmiotu względem stałych punktów podparcia pryzmy pomiarowej (2) oraz punktu pomiarowego czujnika indukcyjnego (4) zapewnia wspornik (8). Przyrząd pomiarowy opiera się na podłożu za pośrednictwem gumowych nóżek, które również zapewniają tłumienie drgań z otoczenia.

W celu weryfikacji koncepcji zastosowania metody odniesieniowej do pomiaru odchyłki falistości powierzchni cylindrycznych części maszyn w warunkach przemysłowych przeprowadzono badania statystyczne, mające wyznaczyć eksperymentalną dokładność metody odniesieniowej DM. Na podstawie wartości średniej względnego błędu przyrządu pomiarowego ROL-2 (względem wzorcowego przyrządu pomiarowego Talyrond 365) oraz przedziału ufności pojedynczego błędu pomiaru odchyłki falistości dla próby elementów walcowych o średniej odchyłce falistości $\overline{R O N t}=3,55 \mu \mathrm{m}$ wyznaczono odpowiednio $D M=48,2 \%$ dla nominalnych wartości parametrów metody odniesieniowej, natomiast dla ich rzeczywistych wartości dokładność metody odniesieniowej $D M=33,3 \%$. Rozpatrując pomiar odchyłki falistości próbek o średniej odchyłce falistości $\overline{R O N t}=26,85 \mu \mathrm{m}$, dla nominalnych wartości parametrów metody uzyskano $D M=28,1 \%$, natomiast dla ich rzeczywistych wartości $D M=22,4 \%$. W przypadku próbek o mniejszej odchyłce falistości uzyskana wartość eksperymentalnej dokładności metody odniesieniowej $D M=33,3 \%$ (dla rzeczywistych wartości parametrów metody odniesieniowej) jest satysfakcjonująca. Jednakże zastosowanie metody odniesieniowej do pomiaru falistości powierzchni cylindrycznych elementów walcowych charakteryzujących się małymi wartościami odchyłki falistości, tj. poniżej $R O N t=3,55 \mu \mathrm{m}$, jest ograniczone.

Przyjmując, że eksperymentalny błąd pomiaru jest wystarczającą miarą dokładności oraz uwzględniając powszechnie akceptowane założenie, że w kontroli technicznej dokładność przyrządu pomiarowego struktury geometrycznej powierzchni powinna się zawierać w granicach $10 \div 25 \%$, na podstawie obliczonej eksperymentalnej dokładności metody odniesieniowej $D M=22,4 \%$ (patrz tabl. IV) można stwierdzić, że metoda odniesieniowa może być zastosowana do pomiaru odchyłki falistości elementów cylindrycznych w warunkach przemysłowych [10]. 
Table IV. The results of statistical tests of the experimental error of waviness measurement by the datum-based method TABLICA IV. Wyniki badań statystycznych eksperymentalnego błędu pomiaru odchyłki falistości metodą odniesieniową

\begin{tabular}{|c|c|c|}
\hline \multicolumn{3}{|c|}{ Próbki o większej odchyłce falistości } \\
\hline \multirow{2}{*}{ Parametry metody odniesieniowej } & $\alpha$ & $59^{\circ} 54^{\prime} 04^{\prime \prime}$ \\
\hline & $\beta$ & $30^{\circ} 11^{\prime} 46^{\prime \prime}$ \\
\hline Liczność & $n_{\mathrm{p}}$ & 50 \\
\hline \multirow{3}{*}{ Względny błąd pomiaru } & $W_{\text {RONtmax }}$ & $0,260 \mu \mathrm{m}$ \\
\hline & $W_{\text {RONtmin }}$ & $-0,255 \mu \mathrm{m}$ \\
\hline & $\bar{W}_{\text {RONt }}$ & $-0,004 \mu \mathrm{m}$ \\
\hline Odchylenie średnie kwadratowe dla pojedynczego błędu pomiaru & s & $0,112 \mu \mathrm{m}$ \\
\hline Odchylenie średnie kwadratowe dla średniej arytmetycznej błędu pomiaru & $S_{\mathrm{r}}$ & $0,016 \mu \mathrm{m}$ \\
\hline Wariancja w próbce & $s^{2}$ & $0,013 \mu \mathrm{m}$ \\
\hline Przedział ufności dla pojedynczego błędu pomiaru & $P=0,95\left(u_{\mathrm{p}}=1,96\right)$ & $-0,004 \pm 0,220 \mu \mathrm{m}$ \\
\hline Przedział ufności dla średniej arytmetycznej błędu pomiaru & $P=0,95\left(u_{\mathrm{p}}=1,96\right)$ & $-0,004 \pm 0,031 \mu \mathrm{m}$ \\
\hline Test istotności dla wartości średniej błędu metody & $\begin{array}{l}t_{\mathrm{s}}=-8,69 \\
t_{\mathrm{s}}<t(P, k)\end{array}$ & Rozbieżność przypadkowa \\
\hline Test istotności dla wariancji średniego błędu metody & $\begin{array}{c}F=3,35 \\
F>F_{\mathrm{kr}}\end{array}$ & Rozbieżność nieprzypadkowa \\
\hline Ocena korelacji pomiędzy wyznaczonymi parametrami odchyłki falistości $R O N t$ & $r=0,65$ & Korelacja umiarkowana \\
\hline Eksperymentalna dokładność metody odniesieniowej & $D M$ & $22,4 \%$ \\
\hline
\end{tabular}

\section{Podsumowanie}

Na Politechnice Świętokrzyskiej przeprowadzono kompleksowe badania teoretyczne i eksperymentalne zastosowania metod odniesieniowych do kontroli struktury geometrycznej powierzchni, a zwłaszcza zarysów kształtów okrągłości i walcowości oraz w ograniczonym zakresie - falistości. Uznano, że metody odniesieniowe są przydatne przede wszystkim do pomiarów elementów w trakcie produkcji, z wykorzystaniem skomputeryzowanych systemów pomiarowych wyposażonych w niezbyt skomplikowane, zmechanizowane przyrządy. Wykazano, że metody odniesieniowe są szczególnie predysponowane do pomiarów dużych części maszyn, bezpośrednio na obrabiarce, podczas realizacji procesu technologicznego, gdyż dla takich elementów nie można zastosować tradycyjnych przyrządów, działających na zasadzie pomiarów zmian promienia $\mathrm{w}$ oparciu o metodę $\mathrm{z}$ obrotowym wrzecionem lub stołem. Do nowatorskich pomiarów metodami odniesieniowymi należy zaliczyć ocenę zarysów walcowości. Do takich pomiarów został wykorzystany zbudowany model matematyczny, który zweryfikowano eksperymentalnie z wykorzystaniem specjalnie skonstruowanych systemów pomiarowych.

Przeprowadzone badania pozwoliły ustalić, że metody odniesieniowe nadają się do oceny falistości powierzchni, ale ze względu na skomplikowany model matematyczny, mogą być przydatne do zarysów ustalonych dla harmonicznych $n$, znajdujących się w przedziale $15<n<50$. Takie zastosowanie zostało zweryfikowane pomiarami eksperymentalnymi.

\section{LITERATURA}

[1] Adamczak S., Zmarzly P., Kozior T., Gogolewski D. “Analysis of the dimensional accuracy of casting models manufactured by fused deposition modeling technology". Engineering Mechanics. (2017): 66-69.
[2] Adamczak S., Zmarzły P., Chmielik I.P. "Investigating mathematical models of waviness measurements of cylindrical elements by the V-block method through computer simulations". $11^{\text {th }}$ IMEKO TC14 Symposium on Laser Metrology for Precision Measurement and Inspection in Industry, LMPMI 2014. (2014): 301-304.

[3] Yunlong W., Wenzhong W., Shengguang Z., Ziqiang Z. "Effects of raceway surface roughness in an angular contact ball bearing". Mech. Mach. Theory. 121 (2018): 198-212, https://doi.org/10.1016/j.mechmachtheory.2017.10.016.

[4] Zmarzły P., Adamczak S., Kozior T., Gogolewski D. "Surface texture quality of models manufactured by additive technology fused deposition modeling". $29^{\text {th }}$ International DAAAM Symposium on Intelligent Manufacturing and Automation, DAAAM 2018. 29, 1 (2018): 853-859, https://doi. org/10.2507/29th.daaam.proceedings.123.

[5] Adamczak S., Zmarzly P., Kozior T., Gogolewski D. “Assessment of roundness and waviness deviations of elements produced by selective laser sintering technology". Eng. Mech. (May, 2017): 70-73.

[6] Thalmann R., Spiller J. "A primary roundness measuring machine". Recent Dev. Traceable Dimens. Meas. III, 5879 (2005): 58790E, https://doi.org/10.1117/12.618219.

[7] Adamczak S., Janecki D., Stepień K. "Qualitative and quantitative evaluation of the accuracy of the V-block method of cylindricity measurements". Precis. Eng. 34, 3 (2010): 619-626, https://doi.org/10.1016/j.precisioneng.2010.03.004.

[8] Adamczak S. „Pomiary geometryczne powierzchni: zarysy kształtu, falistość i chropowatość". Warszawa: Wydawnictwa Naukowo-Techniczne, 2008.

[9] Adamczak S., Zmarzły P., Janecki D. “Theoretical and practical investigations of V-block waviness measurement of cylindrical parts". Metrol. Meas. Syst. 22, 2 (2015): 181-192, https://doi.org/10.1515/mms-2015-0023.

[10] Adamczak S., Zmarzły P. “Accuracy assessment of V-block measurements of waviness profiles of machine parts". Mechanik. 11 (2016): 1630-1631, http://dx.doi.org/ 10.17814/mechanik.2016.11.466. 